\title{
ENVIRONMENTAL ASSESSMENT OF HEAVY METALS CONTENT IN SOIL-PLANT SYSTEM
}

\author{
Gr. Stasiev ${ }^{a *}$, I. Eni ${ }^{\mathrm{b}}$, T. Leah ${ }^{\mathrm{c}}$, \\ ${ }^{a}$ State University of Moldova ,str.Mateevici 60, Chisinau, Moldova \\ ${ }^{\mathrm{b}}$ Ministry of Environment, Cosmonautilor 9, Chisinau, Moldova \\ "Institute of Pedology, Agrochemistry and Soil Protection "Nicolae Dimo”, str.Ialoveni 100, Chsinau, Moldova \\ *ipaps_dimo@mtc.md (+373-22) 43-42-00,(+373-22) 28-48-55
}

\begin{abstract}
The content of heavy metals (Ag, Cd, Sn, Cs, Ba, La, Rb, Sr, Mn, Fe, Cu, Zn) has been determinate in the soil-plant system: cambic chernozem - winter wheat. It was found that the amount of $\mathrm{Ag}, \mathrm{Sb}, \mathrm{Sn}$ and $\mathrm{Ba}$ are accumulating in soil, exceeds the admissible concentration limit. In winter wheat, the content of $\mathrm{Cd}$, $\mathrm{Fe}$ and $\mathrm{Zn}$ exceed the maximum admissible concentrations. The $\mathrm{Rb}, \mathrm{Mn}, \mathrm{Zn}$ accumulates in the winter wheat grains, and $\mathrm{Fe}$ and $\mathrm{Cu}-$ in the vegetal organs of wheat.
\end{abstract}

Keywords: cambic chernozem, winter wheat, heavy metals, concentration, environmental pollution.

\section{Introduction}

Heavy metals are considered hazardous environmental pollutants. Their high concentration in plants causes inactivity of enzymes, disturbing processes of photosynthesis, respiration, transpiration, water regime, and absorption, nutrients movement in plants. Accumulation in great amounts in plants and penetrating trophic cycles, heavy metals causing various toxic diseases in human and animal organisms.

The main local sources of environmental pollution with heavy metals are industrial and municipal wastes, gas and smoke exhaust of the electric power station, uncontrolled application of fertilizers and pesticides [1]. A significant source of environmental pollution has transport that gives annually about 500 tons of harmful substances, including some heavy metals. Exhaust emissions in rural areas consist 36\%, in urban area $-80 \%$. The exhaust gases contain $\mathrm{Pb}$, which share the environment pollution can be up to two thirds. In processes of tire vulcanization is used $\mathrm{Zn}$ and $\mathrm{Cd}$, the grinding or burning these conducts to dispersed elements in the environment. As a result of research on the content of heavy metals $(\mathrm{Pb}, \mathrm{Cd}, \mathrm{Zn}, \mathrm{Cu}, \mathrm{Mn})$ in soils was found a high concentration in the vicinity along roads and auto streets, on both sides [2]. In many cases the concentration of heavy metals in soils exceeds the maximum permissible concentration (MPC) in three times. Plants around of the auto roads are also polluted with heavy metals [3].

In addition to local pollutants, the Republic of Moldova is affected by smoke gas flow entering with air masses from neighboring countries, brought by winds. This impact becomes more intense: in the 80 s the acid rains consisted $1 / 3$ from total amount of rain fall, in the present - about $70 \%[4,5]$. The accumulation of heavy metals in plants from smoke and exhaust gas takes place both by root uptake from soil and foliar from air.

According to the research, most soils of republic are weakly and moderate polluted with heavy metals [6]. To soil pollution with heavy metals contribute the exaggerate administration of fertilizes, which are contained in the composition chemical elements as ballast or added specially (superphosphate ennobled with zinc), soil fertilization with wastes, application of pesticides. Calculations show that mineral fertilizers administrated in the soil in dose of $(\mathrm{NPK})_{100}$, contain in $\mathrm{g} / \mathrm{ha}$ : Pb-10, Ni-2, Zn-50, Cu-36, Cr-59, Cd -2 [7]. During three decades the carbonate chernozem was fertilized annually with high doses of fertilizers, the total quantity of $\mathrm{Zn}$ was $143 \mathrm{mg} / \mathrm{kg}$ [8]. Some guidelines show the MPC of $\mathrm{Zn}$ in soils $-100 \mathrm{mg} / \mathrm{kg}$ [9].

\section{Material and method}

Research has been conducted at the Experimental station "Ivancea" of Institute of Pedology, Agrochemistry and Soil Protection "Nicolae Dimo" on the Cambic chernozem. As organic fertilizer was used sludge from wastewater treatment. Were determinate heavy metals content in soil and plants which are studied and insufucient studied in Moldova. The total content of elements (Ag, Cd, Sn, Cs, Ba, La, Rb, Sr, Mn, Fe, Cu, Zn, Br) in soils and plants was determinate in Laboratory of Nuclear Reactions "Gh. N. Flerov", Institute for Nuclear Research Unit (Dubna), X-ray spectrometric method of determination, Camberra 1000.

\section{Results and discussion}

1. Heavy metals in soils

Silver (Ag) clark in lithosphere is $0,7 \mathrm{mg} / \mathrm{kg}$, in pedosphere - $0,1 \mathrm{mg} / \mathrm{kg}[10,11]$. The average content of $\mathrm{Ag}$ in the parental rocks is $0,35 \mathrm{mg} / \mathrm{kg}$, in soils $-0,5 \mathrm{mg} / \mathrm{kg}$. Optimal amount of Ag varies from 0,1 to $1,8 \mathrm{mg} / \mathrm{kg}$ [12]. The technophility (ratio of element mass produced to his clark content) of Ag is $>10^{10}$ [13]. According to the results amount of $\mathrm{Ag}$ in soils of Moldova varies from 0,4 to $2,0 \mathrm{mg} \backslash \mathrm{kg}$, the avarage content is $1,2 \mathrm{mg} \backslash \mathrm{kg}[14,15]$. Clear regularity in 
the distribution of $\mathrm{Ag}$ in soil profile is not observed. According to gradation the quantity of $\mathrm{Ag}$ in soil can be assessed as medium and high, MPC of Ag is $1 \mathrm{mg} \backslash \mathrm{kg}$ [16]. From this criteria, should be mentioned that in most soils of Moldova the Ag concentration is higher than MPC. In the arable layer of cambic chernozem Ag content varies within 1,0-1,3 mg/ $\mathrm{kg}$ and is evaluated as high (table 1).

Table 1

Heavy metals in Cambic Chernozem clay-loamy, mg/kg

\begin{tabular}{|c|c|c|c|c|c|c|c|}
\hline \multicolumn{2}{|c|}{ Variant and depth, cm } & Ag & Cs & $\mathbf{B a}$ & $\mathbf{L a}$ & $\mathrm{Ce}$ & Nd \\
\hline Control, & $0-20$ & $1,3 \pm 0,1$ & $11 \pm 2$ & $510 \pm 30$ & $50 \pm 5$ & $110 \pm 20$ & $40 \pm 5$ \\
\hline $\mathrm{N}_{120} \mathrm{P}_{4,5} \mathrm{~K}_{60}$, & $0-20$ & $1,0 \pm 0,1$ & $12 \pm 1$ & $490 \pm 30$ & $50 \pm 5$ & $120 \pm 20$ & $40 \pm 5$ \\
\hline Sludge, $80 \mathrm{t} / \mathrm{ha}$, & $0-20$ & $1,3 \pm 0,1$ & $13 \pm 2$ & $480 \pm 30$ & $40 \pm 5$ & $110 \pm 20$ & $40 \pm 5$ \\
\hline Sludge, $80 \mathrm{t} / \mathrm{ha}$, & $20-40$ & $1,3 \pm 0,1$ & $18 \pm 2$ & $500 \pm 30$ & $50 \pm 5$ & $110 \pm 20$ & $40 \pm 5$ \\
\hline
\end{tabular}

Cadmium (Cd) - pollutant, which refers to substances excessively dangerous, I class [17]. Clark's in the litoshre is $0,13 \mathrm{mg} \mathrm{Cd} / \mathrm{kg}$, in pedosphere $-0,5 \mathrm{mg} / \mathrm{kg}[10,11]$. The average content of Cd varies from $0,1-0,6 \mathrm{mg} / \mathrm{kg}$ in parental rocks, to $0,2-0,84 \mathrm{mg} / \mathrm{kg}$ in soils, averaging $0,4 \mathrm{mg} \backslash \mathrm{kg}$ [24]. According to the previously results obtained by the spectrographic metod Cd content in soils varies in limits $1,2-1,5 \mathrm{mg} / \mathrm{kg}$ [8].

The soil samples analyzed in the years 1960-1965, a period without intensive application of chemical fertilizers and possible pollution of soils, the average amount of Cd was $0,41 \mathrm{mg} / \mathrm{kg}$, the limit of variation $0,18-0,84 \mathrm{mg} / \mathrm{kg}$ [18]. The other sources mentioned that the amount of $\mathrm{Cd}$ in soils varies within 0,2-1,2 $\mathrm{mg} \backslash \mathrm{kg}$ [19]. Other authors marked concentrations within $0,76-1,76 \mathrm{mg} / \mathrm{kg}$ [20]. Technophility of $\mathrm{Cd}$ is $10^{8}$ [13]. Annualy with fertilizers are incorporate in soil 3-4 $\mathrm{g} \mathrm{Cd} / \mathrm{ha}[21,22]$. In the arable horizons of fertilizers soil the amount of Cd exeected MPC - $2 \mathrm{mg} \backslash \mathrm{kg}$. In the analyzed soil samples of cambic chernozem the amount of Cd consists 1,2-3,1 mg/kg, the average 1,9 mg/kg [14,15].

Stanium (Sn), the clark in lithosphere is $2,5 \mathrm{mg} / \mathrm{kg}$, in pedosphere $-10 \mathrm{mg} / \mathrm{kg}[10,11]$. The content of $\mathrm{Sn}$ in rocks varies in limits $1-10 \mathrm{mg} \backslash \mathrm{kg}$, average 5,4 $\mathrm{mg} \backslash \mathrm{kg}$ [12]. Technophility - $\mathrm{Sn}>10^{8}$ [13]. MPC of Sn is 4,5 mg/kg, according to gradation, Sn amount is higher - 8-15 mg/kg [16]. MPC value of Sn 4,5 mg/kg in 2,5 times lower than the pedosphere $(10 \mathrm{mg} / \mathrm{kg})$, which considerd the restriction underestimated. In this case is proposed a concentration $20 \mathrm{mg} /$ $\mathrm{kg}$ of $\mathrm{Sn}$ in soils [16]. In the arabile cambic chernoziom Sn content consists $13 \mathrm{mg} / \mathrm{kg}$ and be considered high for soils of Moldova.

Stibium $(\mathrm{Sb})$ as a polluting substance refers to II class moderately hazardous [17]. Clark Sb in litisphere consists - $0,5 \mathrm{mg} / \mathrm{kg}$, in pedosphere $-1,0 \mathrm{mg} / \mathrm{kg}[10,11]$. The average content of Sb in parental rocks is $0,5-3,0 \mathrm{mg} / \mathrm{kg}$, in soils $-1-5 \mathrm{mg} / \mathrm{kg}$, averaging 2,0 mg/kg [12]. Technophility $\mathrm{Sb}>10^{8}$ [13]. According to results the investigated soil contain $\mathrm{Sb}$ in limits 4,3-9,0 mg/kg, averaging $6,6 \mathrm{mg} / \mathrm{kg}[14,15]$. In conformity with gradation 4,1 $\mathrm{mg} / \mathrm{kg}$ this content in soil is considered very high - MPC of Sb in soil is $4,5 \mathrm{mg} / \mathrm{kg}$, for soils of Moldova is proposed 5,0 mg/kg [16]. Mention that Sb concentration in soil samples exceeded the MPC and incadred within the low polluted degree. Arable soil layer contains $7 \mathrm{mg} / \mathrm{kg} \mathrm{Sb}$ and is considered to be weakly polluted.

Cesium (Cs) in the lithosphere is $3,7 \mathrm{mg} / \mathrm{kg}$, in pedosphere $-5 \mathrm{mg} / \mathrm{kg}[10,11]$. The content of this element in rocks and soils of Moldova varies in limits $1-14 \mathrm{mg} / \mathrm{kg}$, averaging $-5 \mathrm{mg} / \mathrm{kg}$ [12]. Technophility Cs $>10^{6}$ [13]. The results show that the content of Cs in soils varies within $8-21 \mathrm{mg} / \mathrm{kg}$, averaging $14,1 \mathrm{mg} / \mathrm{kg}[14,15]$. Increasing the Cs content was detected in fertilized soils with sludge in dose $80 \mathrm{t} / \mathrm{ha}$. In this variant was found a tendency to increase the amount of $\mathrm{Mn}(1300-1590 \mathrm{mg} / \mathrm{kg}), \mathrm{Cr}(100-151 \mathrm{mg} / \mathrm{kg}), \mathrm{Cu}(28-34 \mathrm{mg} / \mathrm{kg}$ [8, 22]. The urbam sludge contain Mn - 160$870 \mathrm{mg} / \mathrm{kg}$, averaging - $300 \mathrm{mg} / \mathrm{kg} ; \mathrm{Cr}-70-830 \mathrm{mg} / \mathrm{kg}$, averaging $-364 \mathrm{mg} / \mathrm{kg} ; \mathrm{Cu}-59-1347 \mathrm{mg} / \mathrm{kg}$, averaging - 486 $\mathrm{mg} / \mathrm{kg}$ [12]. The fertilizer increased the content of elements in soil.

Bariun (Ba) - refers to substances polluting excessively dangerous I class. Clark's in the lithosphere is $650 \mathrm{mg} /$ $\mathrm{kg}$, in pedosphere $-500 \mathrm{mg} / \mathrm{kg}[10,11]$. Ba content in rocks is $60-490 \mathrm{mg} / \mathrm{kg}$, averaging - $360 \mathrm{mg} / \mathrm{kg}$; in soils - 140-640 $\mathrm{mg} / \mathrm{kg}$, averaging - $460 \mathrm{mg} / \mathrm{kg}$ [12]. According to results the Ba content in soils varies within 310-540 mg/kg, averaging $452 \mathrm{mg} / \mathrm{kg}[14,15]$. The MPC of Ba in soils is relatively small - $100 \mathrm{mg} / \mathrm{kg}$, in this context is proposed for soil of Moldova $-1200 \mathrm{mg} / \mathrm{kg}$ [12]. In the experimental samples of cambic chernozem is founded $480-510 \mathrm{mg} / \mathrm{kg}$, being in the moderate class of toxicity.

Strontiun ( $\mathrm{Sr}$ ) - referes to substances polluting excessively dangerous, I class. Clark $\mathrm{Sr}$ in the lithosphere is $340 \mathrm{mg} / \mathrm{kg}$, in pedosphere $-300 \mathrm{mg} / \mathrm{kg}[10,11]$. Sr content in rocks varies within $40-800 \mathrm{mg} / \mathrm{kg}$, averaging $-210 \mathrm{mg} /$ $\mathrm{kg}$, in soils $-50-400 \mathrm{mg} / \mathrm{kg}$, averaging $-240 \mathrm{mg} / \mathrm{kg}$ [12]. MPC of $\mathrm{Sr}$ in soils consists $-600 \mathrm{mg} / \mathrm{kg}$ [16]. In the cambic chernoziom $\mathrm{Sr}$ consists in arable stratum $99 \mathrm{mg} \backslash \mathrm{kg}$ and considered very low $[8,16]$.

Manganese (Mn) concerns as substances polluting excessively dangerous I class. Clark Mn in lithosphere is $1000 \mathrm{mg} / \mathrm{kg}$, in pedosphere $-850 \mathrm{mg} / \mathrm{kg}[10,11]$. Mn content in the rocks is $180-900 \mathrm{mg} / \mathrm{kg}$, averaging $610 \mathrm{mg} / \mathrm{kg}$, in soils $-150-2250 \mathrm{mg} / \mathrm{kg}$, averaging $790 \mathrm{mg} / \mathrm{kg}$ [12]. MPC of Mn in sois is $1500 \mathrm{mg} / \mathrm{kg}$ [16]. In arable horizon of cambic chernoziom $\mathrm{Mn}$ content is $1320 \mathrm{mg} / \mathrm{kg}$ and considered highly toxic. 
Copper $(\mathrm{Cu})$ as a moderate pollutant refers to substances hazardous of II class. Clark's in the lithosphere is $47 \mathrm{mg} / \mathrm{kg}$, in pedosphere $-20 \mathrm{mg} / \mathrm{kg}$ [10,11]. The $\mathrm{Cu}$ content in rocks varies within 2-34 mg/kg, averaging $22 \mathrm{mg} / \mathrm{kg}$, in soils $2-400 \mathrm{mg} \backslash \mathrm{kg}$, averaging - $32 \mathrm{mg} / \mathrm{kg}$ [12]. In the arable horizon of cambic chernoziom content of $\mathrm{Cu}$ is $28 \mathrm{mg} /$ $\mathrm{kg}$, considerate moderately toxic. MPC of $\mathrm{Cu}$ in soils is $60 \mathrm{mg} / \mathrm{kg}$, but it is proposed for soils of Moldovs $-150 \mathrm{mg} / \mathrm{kg}$ [16].

Zinc $(\mathrm{Zn})$ as a pollutant refers to excessively dangerous substances, I class. Clark in the lithosphere is $83 \mathrm{mg}$

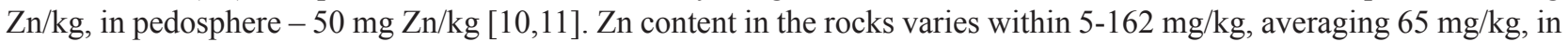
the soils - 10-166 mg/kg, avaraging $71 \mathrm{mg} / \mathrm{kg}$ [12]. In the arable layer of cambic chernozem $\mathrm{Zn}$ amount is $39 \mathrm{mg} / \mathrm{kg}$ is considered low. MPC of $\mathrm{Zn}$ in soil consist $300 \mathrm{mg} / \mathrm{kg}$, it is proposed - $250 \mathrm{mg} / \mathrm{kg}$ [16].

Lanthanum (La) clark in pedosphere is $40 \mathrm{mg} / \mathrm{kg}$ [10,11]. The amount of La in soils varies within $30-60 \mathrm{mg} / \mathrm{kg}$, averaging $44 \mathrm{mg} / \mathrm{kg}[14,15]$. The experimental soil contains the $40-50 \mathrm{mg} \mathrm{La} / \mathrm{kg}$ (tab.1).

Cerium (Ce) clark in pedpsphere is $50 \mathrm{mg} / \mathrm{kg}[10,11]$. The concentration in soils varies in limits $70-130 \mathrm{mg} / \mathrm{kg}$, averaging $99 \mathrm{mg} / \mathrm{kg}$. The experimental soil samples contain Ce within 110-120 mg/kg.

Neodium $(\mathrm{Nd})$ content in soils varies within $30-50 \mathrm{mg} / \mathrm{kg}$, averaging - $35 \mathrm{mg} / \mathrm{kg}[14,15]$. In the experimental soil is founded $40-50 \mathrm{mg} \mathrm{Nd} / \mathrm{kg}$.

\section{Heavy metals in plants}

Silver (Ag) content in cereal grains varies within $0,01-0,1 \mathrm{mg} / \mathrm{kg}$, in vegetal organs of wheat - 0,05-0,2 mg/ $\mathrm{kg}$ [12]. According to researches, the amount of Ag in grains of winter wheat is $0,044 \mathrm{mg} / \mathrm{kg}$, in vegetal organs - $0,026-$ $0,035 \mathrm{mg} / \mathrm{kg}$. The content of Ag in cereal grains in condition of Moldova less than $0,01 \mathrm{mg} / \mathrm{kg}$ is considered deficient, more than $1,0 \mathrm{mg} / \mathrm{kg}$ considered excess toxical [12]. So, the amount of Ag in winter wheat in the ecological aspects is considerate as optimal (tab.2).

Table 2

Heavy metals in winter wheat, $\mathrm{mg} / \mathrm{kg}$ of dry mass

\begin{tabular}{|c|l|c|c|c|c|c|c|c|c|c|}
\hline Variant & Organ & $\boldsymbol{A g}$ & $\boldsymbol{B} \boldsymbol{a}$ & $\boldsymbol{R} \boldsymbol{b}$ & $\boldsymbol{S r}$ & $\boldsymbol{M n}$ & $\boldsymbol{F e}$ & $\boldsymbol{C u}$ & $\boldsymbol{Z n}$ & $\boldsymbol{B r}$ \\
\hline \multirow{3}{*}{ Control } & Grain & 0,044 & 12 & 8,0 & 5,15 & 11,7 & 150 & 9 & 70 & 15,0 \\
\cline { 2 - 11 } & Chaff & 0,044 & 5 & 6,0 & 4,45 & 12,4 & 130 & 5 & 70 & 2,1 \\
\cline { 2 - 11 } & Straw & 0,044 & 8 & 5,6 & 11,68 & 20,1 & 130 & 5 & 70 & 3,5 \\
\hline \multirow{3}{*}{$\mathrm{N}_{120} \mathrm{P}_{4,5} \mathrm{~K}_{60}$} & Grain & 0,044 & 12 & 8,0 & 6,43 & 11,7 & 140 & 9 & 70 & 15,0 \\
\cline { 2 - 11 } & Chaff & 0,032 & 7 & 3,0 & 3,03 & 14,9 & 140 & 5 & 70 & 6,0 \\
\cline { 2 - 11 } & Straw & 0,026 & 21 & 3,8 & 8,03 & 40,0 & 210 & 5 & 70 & 13,0 \\
\hline \multirow{2}{*}{$\begin{array}{c}\text { Sludge, } \\
80 \text { tha }\end{array}$} & Grain & 0,044 & 11 & 3,4 & 7,10 & 85,0 & 280 & 8 & 66 & 15,0 \\
\cline { 2 - 10 } & Chaff & 0,035 & 7 & 5,6 & 2,83 & 34,5 & 160 & 5 & 66 & 9,0 \\
\cline { 2 - 10 } & Straw & 0,035 & 9 & 2,7 & 13,7 & 81,0 & 81 & 6 & 66 & 9,0 \\
\hline
\end{tabular}

Cadmium (Cd) content in cereal grains varies in limits $0,01-0,5 \mathrm{mg} / \mathrm{kg}$, in vegetative organs - 0,01-0,8 mg / kg [12]. According investigation, in the variant with sludge application, $80 \mathrm{t} / \mathrm{ha}$ the quantity of $\mathrm{Cd}$ in $\mathrm{grains}$ is $0,9 \mathrm{mg} / \mathrm{kg}$, in vegetative organs $-0,2-0,3 \mathrm{mg} / \mathrm{kg}$. In condition of Moldova the quantity of $\mathrm{Cd}$ in winter wheat is consider weakly toxic, and $>12 \mathrm{mg} / \mathrm{kg}$ - excessive toxic. Maximum allowable level of $\mathrm{Cd}$ in grains is $0,3 \mathrm{mg} / \mathrm{kg}$, in bakery products $0,02 \mathrm{mg} / \mathrm{kg}[12]$.

Stanium (St) content in winter wheat chaff and straw varies in limits $0,05-0,14 \mathrm{mg} / \mathrm{kg}$.

Cesium (Cs) content in wheat grains is $0,19 \mathrm{mg} / \mathrm{kg}$, in leaves $-<0,1 \mathrm{mg} / \mathrm{kg}$, in straws $-0,14 \mathrm{mg} / \mathrm{kg}$.

Barium (Ba) content in wheat grains is $1-10 \mathrm{mg} / \mathrm{kg}$, in chaff and straw - 10-50 mg/kg [12]. According to researches the amount of $\mathrm{Ba}$ in wheat grains is $11-12 \mathrm{mg} / \mathrm{kg}$, chaff $-5-7 \mathrm{mg} / \mathrm{kg}$, straw $-8-22 \mathrm{mg} / \mathrm{kg}$, leaves $-18-20$ $\mathrm{mg} / \mathrm{kg}$. Ba amount in grains exceeds the normal content. In condition of Moldova Ba content in cereal grains $<1 \mathrm{mg} / \mathrm{kg}$ considered weakly dangerous and $>200$ - surplus of content [12].

Lanthanum (La) content in wheat grains is $0,6 \mathrm{mg} / \mathrm{kg}$, in leaves $-0,4 \mathrm{mg} / \mathrm{kg}$, in the stems - 0,6 mg/kg. As mentioned above, the amount of this element in soil and plants is studied insufficiently.

Rubidium $(\mathrm{Rb})$ content in cereal grains varies within $1-5 \mathrm{mg} / \mathrm{kg}$ [12]. In wheat grains investigated Rb amount varies in limits 3,4-9,9 mg/kg, chaff - 3-6 mg/kg, leaves - 4,0-4,8 mg/kg, strain - 2,7-5,6 mg/kg. The small amount of $\mathrm{Rb}$ was detected in grains on variant with sludge application.

Strontium $(\mathrm{Sr})$ content in cereal grains is $1-15 \mathrm{mg} / \mathrm{kg}$, in vegetal organs - 30-140 mg/kg [12]. According investigations the quantity of $\mathrm{Sr}$ in winter wheat grains consists $-15,5 \mathrm{mg} / \mathrm{kg}$, pulp $-13 \mathrm{mg} / \mathrm{kg}$, in chaff $-2,83-4,45$ $\mathrm{mg} / \mathrm{kg}$, leaves $-17,6-25,6 \mathrm{mg} / \mathrm{kg}$, stems $-8,03-13,7 \mathrm{mg} / \mathrm{kg}$. The quantity of $\mathrm{Sr}$ in wheat grains $<10$ considered poor and $>200$ - toxical [12].

\section{Conclusion}

The concentration of $\mathrm{Ag}, \mathrm{Sb}, \mathrm{Sn}, \mathrm{Ba}$ in the soil exceeds the MPC. High content of $\mathrm{Cd}$ in the arable layer of 
cambic chernoziom can be explained by intensive management of mineral fertilizers containing Cd as ballast. In the variant with sludge ( $80 \mathrm{tha}$ ) the content of Cs increased from 11 to $18 \mathrm{mg} / \mathrm{kg}, \mathrm{Mn}-1230-1590 \mathrm{mg} / \mathrm{kg}, \mathrm{Cr}-100-151$ $\mathrm{mg} / \mathrm{kg}, \mathrm{Cu}-28-34 \mathrm{mg} / \mathrm{kg}$. The quantity of $\mathrm{Cd}, \mathrm{Fe}, \mathrm{Zn}, \mathrm{Ba}$ in wheat grains exceeds MAC. In grains accumulation of Br, $\mathrm{Rb}, \mathrm{Mn}, \mathrm{Zn}, \mathrm{Fe}, \mathrm{Cu}$ is optimal.

\section{References}

[1]. Stasiev Gr. Sursele şi nivelul de poluare tehnogenă a mediului Republicii Moldova cu Metale grele // Analele ştiințifice ale Universităţii de Stat din Moldova, seria „Ştiințe chimico-biologice”. Chişinău, 2002, p.13-16.

[2]. Grigheli Gh., Stasiev Gr. Impactul gazelor de eşapament asupra poluării solurilor cu metale grele // Lucrările conferinței ştiințifice „Solul şi Viitorul”, Chișinău, p.225-227. 2001.

[3]. Stasiev Gr., Grigheli Gh., Iorga E., Formuzachi N. Metalele grele în solurile Moldovei şi nivelul lor de acumulare în producția agricolă şi alimentară // Buletinul Academiei de Ştiințe a Moldovei. Ştiinţe biologice, chimice şi agricole, 1 (292). Chişinău, 2004, p.161-165.

[4]. Brega V., Țărîță A., Stasiev Gr. etc. New Rewired Data for Calculating and Mapping Critical Loads of Nitrogen, sulfur and Heavy Metals for Ecosystems of the Republic of Moldova // Proceeding of the Training Workshop on Critical Loads Calculationa for Air polluants and Mapping in Fast and South East Europe; Chişinău, p.104-112. 2001.

[5]. Brega V., Stasiev Gr., Tărîță A. Calculation and Mapping of Critical Loads for Heavy Metals of Ecosystems in Moldova // Solul - una din problemele principale ale sec.XXI. Lucrările conferinței Internaţionale ŞtiințificoPractice. Chişinău, p. 335-337. 2003.

[6]. Leah T. Criteriile de identificare şi clasificare a solurilor poluate cu metale grele // Rezumatele rapoartelor prezentate la conferinţa ştiinţifică „Problemele agrochimiei în agricultura contemporană”. Chişinău, 1997, p. 113-115.

[7]. Grigheli Gh., Burlacu I., Nedealkov S., Stasiev Gr. Conţinutul metalelor grele în solurile Moldovei şi producția agricolă // Resurse funciare şi acvatice. Valorificarea superioară şi protecția lor. Vol. II. Chişinău, 1998, p.67-69.

[8]. Stasiev Gr., Grigheli Gh., Nedealkov S. ş.a. Metalele grele în solurile Moldovei şi acumularea lor în produsele cerealiere // Simpozion ştiinţific Internaţional „70 ani ai Universităţii Agrare de Stat din Moldova”. Agronomie. Chişinău, 2003, p. 156-157.

[9]. Методические указания по определению тяжелых металлов в почвах сельхозугодий и продукции растениеводства (изд. 2е, переработанное и дополненное). М., 1992, 52 с.

[10]. Виноградов А.П. Геохимия редких и рассеянных химических элементов в почвах. М., Наука, 1957.237 c.

[11]. Виноградов А.П. Среднее содержание химических элементов в главных типах изверженных горных пород земной коры // Геохимия, 1962. №7, с. 555-571.

[12]. Кирилюк В.П. Микроэлементы в компонентах биосферы Молдовы. Кишинев: Pontos, 2006, 156c.

[13]. Перельман А.И. Геохимия элементов в зоне гипергенеза. М.Недра, 1972. 288 с.

[14]. Stasiev Gr., Eni In., Ursu A. Conținutul unor metale grele în solurile Moldovei // Creşterea impactului cercetării şi dezvoltării capacităţii de inovare. Chişinău, 2011.

[15]. Stasiev Gr., Eni In., Ursu A. Evaluarea ecologică a cantităţii unor metale grele în principalele tipuri de soluri ale Republicii Moldova // Mediul Ambiant, nr.3, 2011, p.28-32.

[16]. Кирилюк В.П. Экологическое нормирование химических элементов в почвах и других компонентах биосферы Молдовы // Bioetica, filosofia şi medicina în strategia de asigurare a securităţii umane. Chişinău, CEP „Medicina”. 2010. P.267-270.

[17]. ГОСТ 17.4.1.02-83.

[18]. Рабинович И.З. Кадмий в почвах Молдавии // Изменение плодородия почв Молдавии под влиянием сельскохозяйственного использования. Кишинев, 1984, с.67.74.

[19]. Тома С.И. Микроэлементы в полеводстве Молдавии. Кишинев: Штиинца, 1973. 199 с.

[20]. Бурлаку И., Серженту Е., Григель Г., Плешко Л. Агрохимическая и экологическая оценка состояния почв Молдавии // Raporturile conferinței Ştiințifice „Trecutul, prezentul şi viitorul solurilor Moldovei”. Chişinău, 1996. p.209-223.

[21]. Gunnarson O. Heavy Metals In Fertilizers. Do the Cause Environmental and Health Problems // Fertilizers and Agriculture. V.37. N.35. 1983, p.27-42.

[22]. Глинка К.В., Стасьев Г.Я., Симазев В.Ю. и др. Эффективность использования продуктов очистки дымовых газов теплоэлектростанций в сельском хозяйстве // Эффективность и безопасность химизаций земледелия в Молдавии. Кишинев, 1998, с.58-69. 